\title{
Rosella Flower Extract Prevent Increasing of Interleukin- 6 and Amyloid- $\beta$ Levels in Brain Tissue of Heated Diet-Treated Rats
}

\author{
Ardhiyanti P. Ratna ${ }^{1,2^{*}}$, Setyawati Soeharto ${ }^{3}$, Edi Widjajanto ${ }^{4}$, Silvy A. Falyani ${ }^{1}$, \\ Pia B. Batmomolin ${ }^{1}$

\begin{abstract}
${ }^{1}$ Master Program in Biomedical Sciences, Faculty of Medicine, University of Brawijaya, Malang, Indonesia
${ }^{2}$ Laboratory of Histology, Faculty of Medicine, Al Azhar Islamic University, Mataram, Indonesia

${ }^{3}$ Laboratory of Pharmacology, Faculty of Medicine, University of Brawijaya, Malang, Indonesia
\end{abstract} \\ ${ }^{4}$ Laboratory of Clinical Pathology, Faculty of Medicine, University of Brawijaya, Malang, Indonesia
}

\begin{abstract}
Heated food is a source form of various types Advanced Glycation Endproducts (AGEs). One of which is $N$ carboxymethyl-lysine (CML) that is often used as a sign of the formation of AGEs in the diet. The accumulation of AGEs in the brain can trigger neurodegenerative conditions. It also accelerates the accumulation of Amyloid $\beta$ and proinflammatory cytokines which exacerbate neurodegeneration. Hibiscus sabdariffa $\mathrm{L}$ or rosella known to have antiglication, antioxidant, and anti-inflammatory effects. This study aims to prove the effect of food heating to the increasing levels of CML serum and evaluate the effects of daily intake of Rosella extract IL- 6 levels and Amyloid $\beta$ in the Wistar rats' brain given a diet high of AGEs. This experimental study with post test only control group design was conducted using 25 white male rats Wistar strain (Rattus novergicus) which were divided into 5 groups namely positive control, negative control, the treatment group with rosella dose $200 \mathrm{mg}^{\mathrm{kgBW}}{ }^{-1}, 300 \mathrm{mg} . \mathrm{kgBW}^{-1}$, and $400 \mathrm{mg} . \mathrm{kgBW}^{-1}$. The high diets of AGEs are given for 12 weeks, and it was added to the rosella extract with various doses on the $9^{\text {th }}$ to $12^{\text {th }}$ weeks. The examination of CML serum level, interleukin 6 brain level, and Amyloid $\beta$ of the brain was carried by ELISA. This study found differences between CML serum level of rats which fed a standard diet and the one that was given a heated diet $(p=0.0001)$. It also found that rosella flower extract can prevent the increasing levels of interleukin 6 and Amyloid $\beta$ in the brain tissue of rats which were given a heated diet, and both effective doses were on 200 $\mathrm{mg} . \mathrm{kgBW}^{-1}$.
\end{abstract}

Keywords: Advanced Glycation End products, Amyloid $\beta$, Interleukin 6, N-carboxymethyl-lysine, Rosella.

\section{INTRODUCTION}

Over the last few decades, the consumption of highly processed foods and the ones that contain high sugar and fat has increased dramatically [1]. Changes in diet patterns have resulted in the increased of Advanced Glycation Endproducts (AGEs) which is formed in foods during a warm-up process. AGEs is a Maillard reaction product, where the component of sugars in food react with proteins, causing crossreaction protein, and produce a brownish color with the formation of flavor and aroma components. Various forms of AGEs were produced during the process of heating food [2]. One of which is $\mathrm{N}$-carboxymethyl-lysine (CML) that is often used as a sign of the formation of AGEs in the diet [3].

In the decade of the 80s, Monnier and Cerami, the pioneer in aging process with the

\footnotetext{
* Correspondence address: Ardhiyanti Puspita Ratna

Email : ardhiyanti.pr@gmail.com

Address : Biomedical Program, Faculty of Medicine, University of Brawijaya, Veteran Malang, Malang 65145.
}

theory of glycosylated non-enzymatic, revealed the presence of crosslinks between the long-lived protein, which is mediated by AGEs, that led to a decrease in the function of cells and tissues inthe natural aging process [4]. The role of AGEs in the aging process in the brain or neurodegenerative first revealed in the mid-1990s [5]. Distribution of AGEs are also found in various compartments and parts of the human brain and led to allegations of links between AGEs with neurodegenerative disorders [6].

In the brain, AGEs can disrupt neuronal cells through the formation of covalent bonds directly with the substrate. AGEs extracellular can affect the neurons through its surface receptor namely RAGE. RAGE is a member of the immunoglobulin superfamily that can bind to a large group of ligands such as AGEs and amyloid $\beta(A \beta)$ [7]. The interaction of the ligand-receptor activates signal transduction pathways that are mediated by receptors and affected the cell function [6].

The accumulation of AGEs will also accelerate the accumulation of $A \beta$ [7]. A study also showed there is an activation of the pathway of mitogenactivated kinase protein (MAPK) in response to 
the $A \beta$ fibrils in the aftermath of inflammatory signals of kinase-dependent tyrosine on microglia. Microglial cells exposed to $A \beta$ will secrete inflammatory mediators, one is interleukin 6 [8]. Therefore, AGEs known to play an important role in the development of neurodegenerative diseases [7]. The biggest problem posed by the effects of neurodegenerative disorders is very damaging, but until now, its success rate of treatment is low [9].

Over the past few years, the derived flavonoids have been found helpful in the treatment of neurodegenerative diseases [10]. Flavonoid is a component of polyphenols found in plant food and is divided into six groups: flavonols, flavones, isoflavones, flavanones, flavanols, and anthocyanins [11].

Anthocyanin is a polyphenol in the group of flavonoids that are known as antioxidants [12]. Anthocyanins inhibit glycation and scavenging activity against DPPH and anion superoxide. Anthocyanin resistance mechanism against glycation occurs through barriers against autooxidation of monosaccharides [13]. Anthocyanin also hinder the process of glycation and AGEs binding to its receptor as well as the prevention of lipid peroxidation and inhibition of polyol pathway [14].

Hibiscus sabdariffa $L$. known as Rosella is known to contain phenolic acid compounds such as hibiscus acid and anthocyanins as delphinidin3-sambubioside and cyanidin-3-sambubioside [13]. Research conducted by Peng et al. in 2011 found that Rosella was also able to reduce lipid peroxidation in mouse models of diabetes [15]. Later, research carried by Ademiluyi et al. in 2013 found an anthocyanin content of $121.5 \mathrm{mg} .100 \mathrm{~g}^{-1}$ Rosella [14]. This study aims to prove the effect of heated food on elevated levels of $\mathrm{CML}$ and determine the effect of daily intake Rosella extract on the levels of IL- 6 and Amyloid $\beta$ in wistar rats' brain which given a heated diet.

\section{MATERIAL AND METHOD}

\section{Subject}

This research was experimental study, using post test-only control group design. The animals that were used were white male rats (Rattus norvegicus) Wistar strain, 10-12 weeks of age with 150-180 grams baseline weight. The animals obtained from the Laboratory of Animal Physiology, Faculty of Science and Technology, Maulana Malik Ibrahim State Islamic University Malang. There were 25 animals as samples which were calculated based on the Federer formula. The whole animal was treated in accordance with the provisions of the Helsinki Convention. Ethical Clearance was obtained from the Research Ethics Committee of Health Research Ethics Faculty of Medicine, the University of Brawijaya, issued number 278/EC/KEPK/ 07/2016.

The rats were placed in the individual cages with an area of $500 \mathrm{~m}^{2}$ in a well-ventilated room and sufficient lighting, where the light-dark cycle was set every 12 hours. Its room temperature ranged from $20-26^{\circ} \mathrm{C}$. The cages were cleaned regularly and the husks were replaced every day. After the rats were adapted for one week in a research environment, it then divided into five groups with 5 rats each group that was selected randomly. The negative control group (KN) was given a standard diet BR1 (21-23\% protein, 5\% fat, $40-45 \%$ starch, $5 \%$ crude fiber) which was not heated. Positive control group (KP) were given a high AGEs diet, such as BR1's feeds which was heated using an oven with the temperature of $150^{\circ} \mathrm{C}$ for 15 minutes. $R_{1}$ was a group of rats fed a high AGEs diet and rosella flower extract ethanol at a dose of $200 \mathrm{mg} \cdot \mathrm{kgBW}^{-1}$. $\mathrm{R}_{2}$ was a group of rats fed a high AGEs diet and ethanol extracts of rosella a dose of $300 \mathrm{mg} . \mathrm{kgBW}^{-1}$. $\mathrm{R}_{3}$ was a group of rats fed a high AGEs diet and extract ethanol of rosella flower at a dose of $400 \mathrm{mg}^{\mathrm{kgBW}}{ }^{-1}$. The Rosella was obtained from Materia Medika Hall Batu City.

During the first 8 weeks, KP, R,$R_{2}$ and $R_{3}$ groups were given $B R 1$ heated feed diet only, while KN was fed by BR1 which was not heated. Next, in the $9^{\text {th }}$ week, the levels of $N$ Carboxymethyl-lysine (CML) serum in all groups was measured. Then, the KN group was fed by not heated $B R 1$ diet, while the $R_{1}, R_{2}, R_{3}$ groups were fed BR1 heated and ethanol extract of rosella various doses orally, and the KP group was only fed by BR1 heated only. The treatment was held for 4 weeks.

At the $13^{\text {th }}$ week, the rats were fasted for 8 hours, then terminated by cervical dislocation method. Next, the organ removal was done from the brain directly. Surgery was performed in the cranial area that is on the skull, the brain was separated and the third medial or part of the cerebrum was taken. Then, the brain tissue was put in a pot filled with Phosphate Buffer salineazide (PBS-azide) pH 7.4.

\section{Data Collection}

After 8 weeks feeding of a high AGEs diet, then the levels of $\mathrm{N}$-Carboxymethyl-lysine (CML) 
serum in all groups was measured at the $9^{\text {th }}$ week. Measurement of serum CML aimed to examine the differences between each group and to ensure increasing of $\mathrm{CML}$ serum level before starting treatment with an extract of rosella. At the $9^{\text {th }}$ week, the rat's blood was taken through the medial canthus orbita using a hematocrit micropipette. Blood was collected in $2 \mathrm{~mL}$ tube. Furthermore, it was centrifuged at $3000 \mathrm{rpm}$ for 20 minutes. Next, take the supernatant and perform protocol conformance checks CML ELISA Kit (BT Laboratory catalog no.E1374Ra). Rats that had taken blood was returned to the cage and continued its research procedures.

The measurement of interleukin 6 (II-6) and amyloid $\beta$ of the brain tissue were performed using ELISA method. After the rats were terminated at week $13^{\text {th }}$ and the brain was taken, then was examined for levels of Interleukin 6 and amyloid $\beta$ in the tissue. Sample preparation was done by taking 0.5 gram of brain tissue then ground it up, then added with $300 \mu \mathrm{L}$ mixture PIC and RIPA buffer solution, then the mixture is homogenized by vortex and incubated at $37^{\circ} \mathrm{C}$ for 10 minutes, and the supernatant was taken. The supernatant was obtained to examine levels of interleukin 6 according to the protocol of ELISA Kit IL-6 (BT Laboratory catalog no.E0135Ra) and the protocol ELISA Kit $A \beta$ (BT Laboratory catalog no.E0093Ra).

\section{Data analysis}

Data were analyzed statistically. Data normality was tested by the Shapiro-Wilk test. Homogeneity of data was tested by Levene's test. CML levels to compare the differences between the groups fed standard diet and high AGEs diet conducted independent t-test. Effect of Rosella extract on levels of IL6 and $\beta$ Amyloid in the brain was tested by ANOVA followed by Tukey HSD Post Hoc test. The significance level used more than $95 \%$ ( $p$-value $<0.05$ ).

\section{RESULT AND DISCUSSION Levels of serum CML}

The measurements of serum levels of CML in mice fed with standard diet and the group fed high AGEs diet showed that serum levels of CML in the group fed with heated diet are higher than those fed standards. The average serum levels of CML in the group fed which was heated by $159 \pm$ $8.23 \mathrm{ng} \cdot \mathrm{mL}^{-1}$, whereas in the standard feed group $51.6 \pm 33.66 \mathrm{ng} \cdot \mathrm{mL}^{-1}$, as shown in Figure 1. In the independent $t$-test obtained by value t-count 6930 with $p$-value 0.001 . A P-value less than 0.05
( $P<0.05)$ shows that there are significant differences between the CML levels of rats that were fed with oven-heated diet and the nonheated diet. So there is an increased level of serum CML of rats that given oven heated diet.

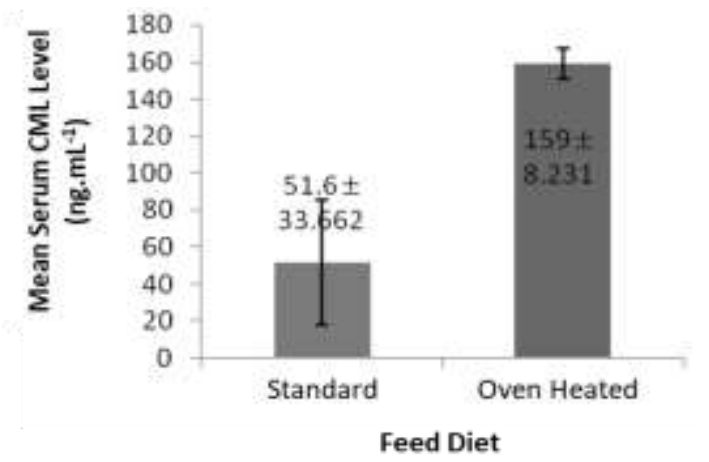

Figure 1. The Mean of CML serum levels

Description: Standard is group that given non heated BR-1 diet, oven heated is group that given oven heated BR-1 diet

\section{Brain tissue levels of Interleukin 6}

Measurements result of interleukin 6 levels in rat brain tissue showed that KP group is higher than other groups, while the R3 group showed the lowest results. The average levels of interleukin 6 from each group is KN $2.21 \pm 3.602$ $\mathrm{ng} \cdot \mathrm{mL}^{-1}, \mathrm{KP} 14.8 \pm 7.08 \mathrm{ng} \cdot \mathrm{mL}^{-1}, \mathrm{R}_{1} 4.014 \pm 0.513$ ng. $\mathrm{mL}^{-1}, \mathrm{R}_{2} 2.402 \pm 0.763 \mathrm{ng} \cdot \mathrm{mL}^{-1}$ and R3 $2.002 \pm$ $0.639 \mathrm{ng} \cdot \mathrm{mL}^{-1}$. Overview of Mean interleukin 6 levels in the brain tissue of mice shown in Figure 2.

Based on the results of the ANOVA test, was obtained $p$-value of 0.000 , less than $\alpha=0.05$ ( $p$ $<0.05$ ). So it can be concluded that there is a significant influence on the administration of Rosella extract with several different doses on levels IL- 6 in the brain tissue of mice.

Since the administration of rosella flower extract has a significant effect on brain levels of IL-6, then continued with Post hoc testing by comparing with other groups to seek which dose is most effective. Based on the test results Tukey HSD known that the decrease of brain levels of IL-6 was significantly demonstrated in all groups that were given rosella flower extract, either a dose of $200 \mathrm{mg} . \mathrm{kgBW}^{-1}, 300 \mathrm{mg} . \mathrm{kgBW}^{-1}$, or a dose of $400 \mathrm{mg} . \mathrm{kgBW}^{-1}$. Groups of rats given the extract of Roselle at all doses had average levels of the IL- 6 brain did not differ significantly with the negative control group mice. This shows that the rosella extract can reduce levels of the IL- 6 brain to near rats given feed without heating.

On the correlation between changes in the rosella extract dose levels of IL-6, -0.649 
correlation coefficient with p-value 0.002 (p $<0.05)$. This suggests a significant association between changes in the rosella extract dose levels of IL-6. -0.649 Correlation coefficient indicates the level of the relationship is strong enough, where the negative sign indicates the opposite relationship. This means that increasing doses of the rosella extract will be followed by a decrease in the levels of IL- 6 and vice versa.

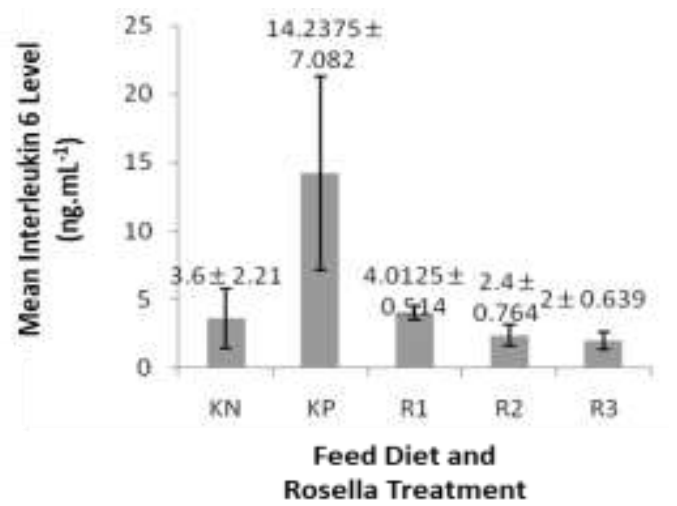

Figure 2. Mean of Interleukin 6 Levels of Brain Tissue Description:

$\mathrm{KN}$ = negative control (standard feed, without extract)

$\mathrm{KP}=$ positive control, fed with heated-food without extract

$\mathrm{R}_{1}$ = treatment group 1 (fed with heated food + Rosella flower ethanol extract $200 \mathrm{mg}^{\mathrm{kgBW}}{ }^{-1}$ )

$\mathrm{R}_{2}$ = treatment group 2 (fed with heated food + Rosella flower ethanol extract $300 \mathrm{mg}^{\circ} \mathrm{kgBW}^{-1}$ )

$R_{3}=$ treatment group 3, (fed with heated food + Rosella flower ethanol extract $400 \mathrm{mg}^{\mathrm{kgBW}} \mathrm{kg}^{-1}$ )

\section{Amyloid $\beta$ levels of brain tissue}

Measurement of amyloid $\beta$ levels in rat brain tissue KP group showed a higher level than other groups, while the $R_{3}$ group showed the lowest results. The average levels of Amyloid $b$ from each group was KN $21.3 \pm 4.655$ pg. $\mathrm{mL}^{-1}, \mathrm{KP} 93$. $454 \pm 4.024$ pg. $\mathrm{mL}^{-1}, \mathrm{R} 123.04 \pm 2.364$ pg. $\mathrm{mL}^{-1}, \mathrm{R} 2$ $20.18 \pm 1.556 \mathrm{pg} \cdot \mathrm{mL}^{-1}$ and R3 $15.54 \pm 2.77 \mathrm{pg} \cdot \mathrm{mL}^{-1}$. Mean level of amyloid $\beta$ in the brain tissue of rats shown in Figure 3.

Based on the results of the analysis using ANOVA, obtained $p$-value of 0.000 , less than $\alpha=$ 0.05 ( $p<0.05)$, so that can be concluded that there is a significant influence on the administration of rosella extract with several different doses on amyloid $\beta$ levels in rats brain tissue.

As the administration of rosella flower extract had significant effect on amyloid $\beta$ levels. then continued with Post hoc test by comparing with other groups to seek which rosella extract dosage is most effective. Based on the test results Tukey HSD known that decreased levels of
Amyloid b significantly demonstrated in all groups were given a rosella flower extract, either

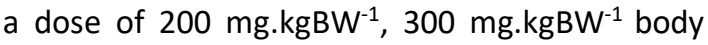
weight, or a dose of $400 \mathrm{mg} . \mathrm{kgBW}^{-1}$. Groups of rats given the rosella extract at all doses had average levels of amyloid $\beta$ brain did not differ significantly with the negative control group rats. This shows that the rosella extract can lower brain levels of amyloid $\beta$ to nearly rats given feed without heating.

On the correlation between changes in the rosella extract dose levels of amyloid $\beta$, the correlation coefficient was -0.837 with $p$-value 0.000 ( $p<0.05)$. This suggests a significant association between changes in the rosella extract dose levels of Amyloid $\beta$. -0.649 Correlation coefficient indicates the level of the relationship is strong enough, where the negative sign indicates the opposite relationship. This means that increasing doses of the extract of roselle will be followed by decreased levels of Amyloid $b$ and vice versa.

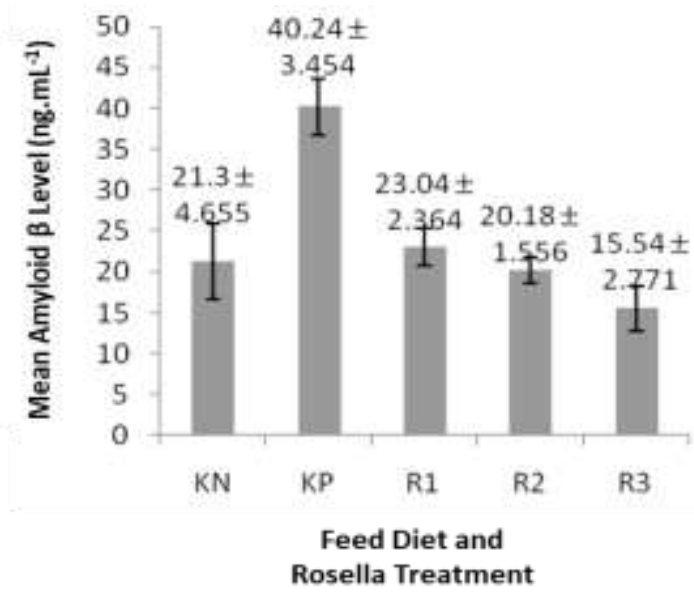

Figure 3. Mean levels of Amyloid $\beta$ of brain tissue Description:

$\mathrm{KN}=$ negative control (standard feed, without extract)

$\mathrm{KP}=$ positive control, fed with heated-food without extract

$R_{1}=$ treatment group 1 (fed with heated food + Rosella flower ethanol extract $200 \mathrm{mg}^{\mathrm{kgBW}} \mathrm{kg}^{-1}$ )

$\mathrm{R}_{2}$ = treatment group 2 (fed with heated food + Rosella flower ethanol extract $300 \mathrm{mg}^{\mathrm{kgBW}} \mathrm{kg}^{-1}$ )

$\mathrm{R}_{3}$ = treatment group 3, (fed with heated food + Rosella flower ethanol extract $400 \mathrm{mg}^{\mathrm{kgBW}}{ }^{-1}$ )

\section{DISCUSSION}

This study aims to prove the effect of food heating on the increase of circulating AGEs, especially CML. It also evaluates the effect of ethanol extract of roselle flowers on levels of interleukin 6 and amyloid $\beta$ in the brain tissue of rats were given a high AGEs diet. Animals used were white rats (Rattus novergicus) male Wistar 
strain by the age of 10-12 weeks. Selection of the rats as a research subject is because rats are the experimental animals were easily controlled and blood or tissues can be collected in relatively high amounts. In addition the study treatment is given orally, then the use of rats is very helpful, because the presence of stomach valve, that make rats can't vomit [25]. The age of rats of 2-3 months can be analogized as adolescence in humans [16].

Animals were fed heated BR1. BR1 feed compositions containing $21-23 \%$ protein, $5 \%$ fat, $40-45 \%$ starch and $5 \%$ crude fiber. Heating was conducted using the oven for 15 minutes at $150^{\circ} \mathrm{C}$. The heating method draws on previous research, in which the heating of the meat by baking at a temperature of $150^{\circ} \mathrm{C}$ for 15 minutes, which is able to increase CML doubled compared with the controls [1].

The feeding was carried out for 8 weeks, then the experimental animals treated with rosella flower extract for 4 weeks, while still given heated diet. Rosella extract is done in three doses of $200 \mathrm{mg}, 300 \mathrm{mg}$, and $400 \mathrm{mg}$. The range of doses taken based on the results of previous research, which is known the dose of extract

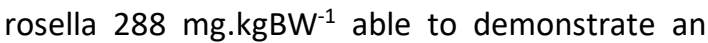
anti-inflammatory effect on the rat model of diabetes induced by Streptozotocin [17]. The feeding for 12 weeks analogous to exposure to food processed by heating in humans during 6.5 years. Known comparison of the human years equal to 13 days in rats [16]. Long-term exposure of heated food potentially be a source of AGEs for humans, accumulation of AGEs is higher in tissues and circulation, has the potential to be pathogenic, which will develop into a variety of chronic diseases [18].

In this study, we found that the CML serum level of the group that given oven heated food is higher than the standard group $(p=0.0001)$. Ncarboxymethyl-lysine (CML) is often used as a marker of the formation of AGEs in the diet. CML can be formed from Amadori product that is fructolysin, produced an unstable intermediate and then oxidized to form CML [3]. The process of formation of Amadori product in the Maillard reaction occurs during the processing of meal by heating. The reaction will turn food into a brownish color, aroma onset, as well as produce better taste. When the food is heated at high temperatures, a chemical reaction between an amino acid group with a reducing sugar which will improve the taste and gives a brownish color.
This reaction is used in the food industry to change the flavor, color, and aroma of food [19].

Heated diet in this study aims to improve the content of AGEs, in this case, the CML. AGEs are formed during the cooking process such as roasting, frying or baking. Food processing involving high temperatures will lead to the accumulation of AGEs in the body increases dramatically [20]. Dietary AGEs are known to be important resources for the overall amount of AGEs in the body. Methods of cooking with dry heat can increase levels of dietary AGEs. The increase in AGEs in the method can achieve a 100-fold compared with raw foods [2].

Once consumed, $10 \%$ of AGEs or also known as glycotoxin will be absorbed into the circulation, $2 / 3$ will remain in the body, and only $1 / 3$ that excreted through renal after 3 days of consumption [21]. Unexcreted glycotoxin will react with cells and tissues, it's also active and causes pathological effects. Total accumulation of exogenous glycotoxin may exceed endogenous glycotoxin [22]. This explanation is consistent with the findings obtained in this study, where the average level of CML serum of rats fed a diet high in AGEs, which are induced by heated diet, almost 3-fold higher compared to the group standard diet.

In this study, after rats were induced by administration of a high AGEs diet from the heated food, then the rats were treated with the rosella extract (Hibiscus sabdariffa $\mathrm{L}$ ). Then we explored the effect on the levels of interleukin 6 (IL-6) in the brain tissue of rats were given high AGEs diet. The results showed a significant effect on the extract of Roselle with several different doses of the levels of IL- 6 on brain tissue of rats, which was obtained $p$-value of 0.000 ( $p<0.05$ ). Results of post hoc test showed a dose of $200 \mathrm{mg}$ is an effective dose for lowering the levels of brain IL-6. While the correlation test obtained a strong relationship between the provision of roselle extract with decreased levels of IL-6.

Rosella has many active compound content which is able to act as anti-oxidants. Rosella contain flavonoids, anthocyanins, alkaloids, bsitosterol and ascorbic acid [22]. Per 100 grams of rosella contained $140.13 \mathrm{mg}$ of ascorbic acid and total anthocyanins as much as $622.91 \mathrm{mg}$. It is known that anthocyanins have antioxidant effects that high compared to other antioxidants, such as vitamin $E$, ascorbic acid and $\beta$-carotene [23].

Anthocyanins, such as cyanidin and delphinidin, is able to inhibit the expression of 
inflammatory mediators [23]. Delphinidin 3sambubioside (DP3-Sam), one of Hibiscus anthocyanin which is derived from Hibiscus sabdariffa petals. In cell models, DP3-Sam and delphinidin (Dp) can reduce levels of inflammatory mediators such as iNOS, NO, IL-6, MCP-1 and TNF- $\alpha$ induced by LPS, via down regulation of pathways signal NF KB and MEK1/2 - ERK1 / 2 [24]. In the study conducted Mardiah et al, 2015, found that the extract of roselle $288 \mathrm{mg} /$ day can reduce the inflammation in rats induced by streptozotosin, through the mechanism of barriers to free radicals [17]. This is consistent with recent research that indicate a significant influence of rosella extract on levels of IL-6 brain.

The results of this study also found that there is a significant influence on the awarding of rosella flower extract with several different doses to levels of amyloid $\beta$ (A $\beta)$ of the brain. Known $p$ value of $0.000(p<0.05)$. Results of post hoc test show an effective dose is in the dose of 200 mg.kgBW ${ }^{-1}$.In addition correlation coefficient was -0.837 with $p$-value $0.000(p<0.05)$. This suggests a significant relationship between dose changes rosella extract with $A \beta$ levels. Where the rosella extract dose increase will be followed by decreased levels of $A \beta$.

Neurodegeneration induced by oxidative stress that is associated with the increasing of the $A \beta$ deposits. $A \beta$ will attach to the neuron membrane or glial cell and generate oxygendependent free radicals which then cause lipid peroxidation and protein oxidation. $A \beta$ causes the release of lipid membranes of neurons, resulting in disruption of homeostasis and loss of neuronal function. The loss of membrane integrity that caused by free radicals generated by $A \beta$ leads to dysfunction of cellular, such as the inhibition of ion-motive ATPase inhibition retrieval systems glutamate from $\mathrm{Na}^{+}$-dependent glial cells as a consequence of excitatory neuron receptors N-methyl-D-aspartate (NMDA) which can cause a loss of synapses in neurons, loss of calcium homeostasis, loss of transporter protein function, impaired signaling pathway, and activation of nuclear transcription factors and apoptotic pathways [25].

Anthocyanins can protect neurons from damage induced by the accumulation of $A \beta$. Anthocyanins are known to maintain homeostasis of calcium $\left(\mathrm{Ca}^{2+}\right)$ intracellularly. Disruption of homeostasis of $\mathrm{Ca}^{2+}$ itself apart will disrupt membrane integrity and function of the synapse and triggers activation of apotosis mediated by mitochondrial disorders [26]. Other studiy also found that the disruption of homeostasis of $\mathrm{Ca}^{2+}$ is also responsible for the increased production of peptide $A \beta$, resulting in a cycle of degenerative which resulted in increased apoptosis and impaired function of the synapse. Anthocyanin is a free radical scavenger potent and able to detoxify the oxidative damage by reducing ROS and or strengthen the work of enzymatic antioxidants [27]. the results of these studies support the results of recent research which shows that rosella extract has significant effect on brain levels of $A \beta$.

\section{CONCLUSION}

This study concluded that the heated diet may increase the CML serum levels by 3 times compared to the non-heated diet. It also found that Rosella flower extract at a dose of 200 $\mathrm{mg} /$ day effectively prevent the increasing of interleukin 6 and Amyloid $\beta$ leveles in the brain tissue of rats that were given a high AGEs from the heated feed.

\section{REFERENCES}

[1] Henle, T. 2009. Maillard reaction of proteins and advanced glycation end products (AGEs) in food. In: Stadler, R.H., D.R. Lineback (Eds). Process-Induced Food Toxicants. John Wiley \& Sons, Inc. Hoboken, NJ. 215-242.

[2] Uribarri, J., S. Woodruff, S. Goodman, W. Cai, X. Chen, R. Pyzik, A. Yong, G.E. Striker, H. Vlassara. 2010. Advanced glycation end products in foods and a practical guide to their reduction in the diet. J. Am. Diet. Assoc. 110. 911-916.

[3] Ames, J.M. 2008. Determination of $\mathrm{N} \varepsilon$ (Carboxymethyl)lysine in foods and related systems. Ann. NY Acad. Sci. 1126. 20-24.

[4] Jerums, G., S. Panagiotopoulos, J. Forbes, T. Osicka, M. Cooper. 2009. Evolving concepts in advanced glycation, diabetic nephropathy, and diabetic vascular disease. Arch. Biochem. Biophys. 419. 55-62.

[5] Simard, E., T. Söllradl, J.S. Maltais, J. Boucher, P. D’Orléans-Juste, M. Grandbois. 2015. Receptor for Advanced Glycation EndProducts signaling interferes with the vascular smooth muscle cell contractile phenotype and function. PLOS ONE 10(8). e0128881.

[6] Srikanth, V., B. Westcott, J. Forbes, T.G. Phan, R. Beare, A. Venn, S. Pearson, T. Greenaway, V. Parameswaran, G. Münch, 
2013. Methylglyoxal, cognitive function and cerebral atrophy in older people. J. Gerontol. A Biol. Sci. Med. Sci. 68(1). 68-73.

[7] Takuma, K., F. Fang, W. Zhang, S. Yan, E. Fukuzaki, H. Du, A. Sosunov, G. McKhann, Y. Funatsu, N. Nakamichi, T. Nagai, H. Mizoguchi, D. Ibi, O. Hori, S. Ogawa, D.M. Stern, K. Yamada, S.S. Yan. 2011. RAGEmediated signaling contributes to intraneuronal transport of amyloid-beta and neuronal dysfunction. Proc. Natl. Acad. Sci. USA. 106. 20021-20026.

[8] Li, J., D. Liu, L. Sun, Y. Lu, Z. Zhang. 2012. Advanced Glycation End Products and neurodegenerative diseases: mechanisms and perspective. J. Neurol. Sci. 317. 1-5.

[9] Yamamoto, A., A. Simonsen. 2011. The elimination of accumulated and aggregated proteins: a role for aggrephagy in neurodegeneration. Neurobiol. Dis. 43. 17-28.

[10] Vauzour, D., A.R. Mateos, G. Corona, M.J.O. Concha, J.P.E. Spencer. 2010. Polyphenols and human health: prevention of disease and mechanisms of action. Nutrients. 2. 1106-1131.

[11] Spencer, J.P., D. Vauzour, C. Rendeiro. 2009. Flavonoids and cognition: the molecular mechanisms underlying their behavioural effects. Arch. Biochem. Biophys. 492. 1-9.

[12] Shipp, J., E.M. Abdel-Aal. 2010. Food applications and physiological effects of anthocyanins as functional food ingredients. Open Food Sci. J. 4. 7-22.

[13] Ubani, C.S., P.E. Joshua, A.N. Oraeki. 2010. Influence of aqueous extract of Hibiscus sabdariffa calyces on lipid profile of phenobarbitone induces Wistar albino rats. J. Pharm. Res. 3(2). 319-324.

[14] Ademiluyi, A.O., G.Oboh, O.J. Agbebi. 2013. Anthocyanin - rich red dye of Hibiscus Sabdariffa calyx modulates Cisplatininduced Nephrotoxicity and oxidative stress in rats . Int. J. Biomed. Sci. 9(4). 243-248

[15] Peng, X., K.W. Cheng, J. Ma, B. Chen, C.T. Ho, C. Lo, F. Chen, M. Wang. 2008. Cinnamon bark proanthocyanidins as reactive carbonyl scavengers to prevent the formation of advanced glycation end products. J. Agr. Food Chem. 56. 1907-1911.

[16] Sengupta, P. 2013. The laboratory rat: relating its age with humans. Int. J. Prev. Med. 4(6). 624-630.

[17] Mardiah, F.R. Zakaria, E. Prangdimurti, R. Damanik. 2015. Anti-inflammatory of purple roselle extract in diabetic rats induced by Streptozotocin. Proc. Food Sci. 3. 182-189.

[18] Fang, H., L. Wang, S. Zhang, H. Liu, J. Li. 2014. Advanced glycation end products (AGEs) formation in high protein foods processing model system. J. Chinese Inst. Food Sci. Technol. 14. 28-34.

[19] Tamanna, N., N. Mahmood. 2015. Food processing and maillard reaction products: effect on human health and nutrition. Int. J. Food Sci. 1-6.

[20] Contreras, C.L., K.C. Novakofski. 2010. Dietary advanced glycation end products and aging. Nutrients. 2. 1247-1265.

[21] Degen J, H. Beyer, B. Heymann, M. Hellwig, T. Henle. 2014. Dietary influence on urinary e xcretion of 3-deoxyglucosone and its metabolite 3-deoxyfructose. J. Agric. Food Chem. 62. 2449-2456.

[22] Semba, R.D., E.J. Nicklett, L. Ferrucci. 2010. Does accumulation of Advanced Glycation End Products contribute to the aging phenotype? J. Gerontol. Med. Sci. 65A(9). 963-975.

[23] Hou, D.X., T. Yanagita, T. Uto, S. Masuzaki, M. Fujii. 2005. Anthocyanidins inhibit cyclooxygenase-2 expression in LPS-evoked macrophages:structure-activity relationship and molecular mechanisms involved. Biochem. Pharmacol. 70. 417-425.

[24] Sogo, T., N. Terahara, A. Hisanaga, T. Kumamoto, T. Yamashiro, S. Wu, K. Sakao, D.X. Hou. 2015. Anti-inflammatory effects of Delphinidin 3-Sambubioside. Biochem. Mol. Biol. Int. 41(1). 58-65.

[25] Richardsz, S.S., R.A. Sweet. 2009. Dementia. In: Sadock, B.J., V.A. Sadock, P. Ruiz. Comprehensive text book of psychiatry Vol $1,9^{\text {th }}$ Ed. Lippincott Williams and Wilkins. Philadelphia. 1176-1185.

[26] Kawahara, M., M. Kato-Negishi. 2011. Link between aluminum and the pathogenesis of Alzheimer's disease: the integration of the aluminum and amyloid cascade hypotheses, Int. J. Alzheimer Dis. DOI: 10.4061/2011/ 276393.

[27] Butterfield, D.A., A.M. Swomley, R. Sultana. 2013. Amyloid beta-peptide (1-42)-induced oxidative stress in Alzheimer disease: importance in disease pathogenesis and progression. Antioxid. Redox Signal. DOI:10.1089/ars.2012.5027. 